\title{
MALE SEXUAL DEVELOPMENT
}

B. COLENBRANDER, M.T. FRANKENHUIS $\dagger$ and C.J.G. WENSING

Department of Anatomy, Veterinary Faculty, State University of Utrecht, The Netherlands

Sexual development is an array of processes which takes place in a regular sequence. During development the body which is sexually bipotential differentiates in either a male or female direction. The first step in this development is determined when the ovum is fertilized with either a $19 \mathrm{X}$ or a $19 \mathrm{Y}$ sperm cell, the pig having $38(2 n)$ chromosomes. The principal

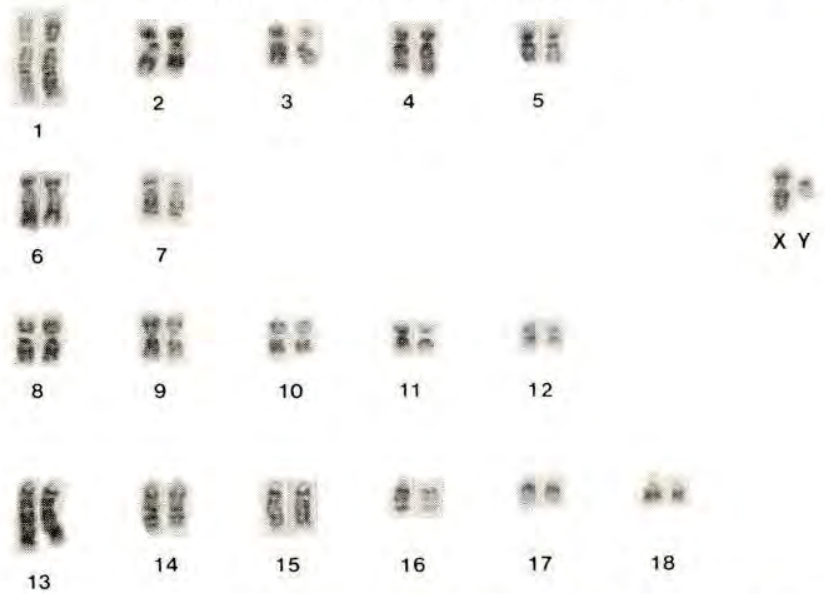

Figure 1.1 G-banded metaphase chromosomes from a cultured blood lymphocyte. The G-banding procedure included treatment with trypsin and staining with Giemsa. For a detailed description of chromosomal banding patterns in the pig see Lin et al. (1980). By courtesy of Dr A.A. Bosma

task of the $\mathrm{Y}$ chromosome is to direct the embryonic indifferent gonad to differentiate as a testis. This chromosome is rather limited in size in most mammals (Figure 1.1).

Irrespective of chromosome constitution, the anlage of the genital system is indifferent i.e. no morphological difference in gonadal or accessory genital structures is observed between the sexes in the first stages of embryonic development. The mammalian embryo has a tendency to

$\uparrow$ Also of Department of Histology and Cell Biology, Medical Faculty, State University of Utrecht, The Netherlands 
develop into a female. Male development is due to the intervention of major regulatory genes. One is Y-linked and specifies a plasma membrane protein ( $\mathrm{H}-\mathrm{Y}$ antigen). Testicular differentiation does not occur in the absence of $\mathrm{H}-\mathrm{Y}$ antigen. Moreover, an $\mathrm{X}$-linked gene regulates the function of the H-Y structural gene (Ohno, 1977; Wachtel and Koo, 1978). Development of the indifferent gonad into a testis is then induced. Subsequently the testis produces hormones that induce phenotypic male development. Differentiation of the male accessory genital organs is androgen-dependent, as is the sex-specific differentiation of a number of nuclei in the central nervous system (Dörner, 1976). An X-linked gene mediates the responsiveness of target cells to steroid hormones (androgens) produced by the testis (Ohno, 1977; Wachtel, 1979).

In the pig three periods of morphological and functional differentiation of the testis can be distinguished. The first period starts with gonadal differentiation at 26 days post coitum and lasts until approximately 60 days post coitum; the second is the perinatal period and the third from puberty onwards. In this review we will focus attention on the morphological and endocrine aspects of testicular development, before adulthood.

\section{Early foetal period}

The indifferent gonad can be recognized at approximately 21 days post coitum, as a bilateral proliferation of mesenchymal blastema covered by coelomic epithelium along the medial side of the mesonephros (Allen, 1904; Black and Erickson, 1968; Pelliniemi, 1975a). The surface epithelium extends as primitive cords into the gonadal blastema. The primordial germ cells, which have reached the gonad by amoeboid movements, (Jirasek, 1976) are located in the mesenchyme under the surface epithelium and in the cords. They increase in number by mitosis. At 24 days post coitum the male and female gonads are morphologically similar. An indication of testicular differentiation can be seen at the age of 26 days, when the primordial germ cells become entirely enclosed within the cords. The cords are separated from the adjacent mesenchyme by a partial discontinuous basal lamina (Pelliniemi, 1975b).

\section{Leydig cells}

Leydig cells appear at the age of 30 days. They proliferate rapidly to reach a maximal stage of development at approximately 38 days post coitum.This is followed by a substantial regression in their number and size (Ancel and Bouin, 1903; Allen, 1904; Whitehead, 1904; Moon and Hardy, 1973).

The well-differentiated Leydig cells are characterized by the presence of a considerable amount of tubular and/or vesicular smooth endoplasmic reticulum (SER). The rough endoplasmic reticulum (RER) is scanty and consists of two types: long and short profile RER. The long type is situated in close proximity to the mitochondria (van Vorstenbosch, Colenbrander and Wensing, 1981). There can be an intimate contact between Leydig cells and gap junctions are common as shown in Figure 1.2(a) and (b). 
(a)

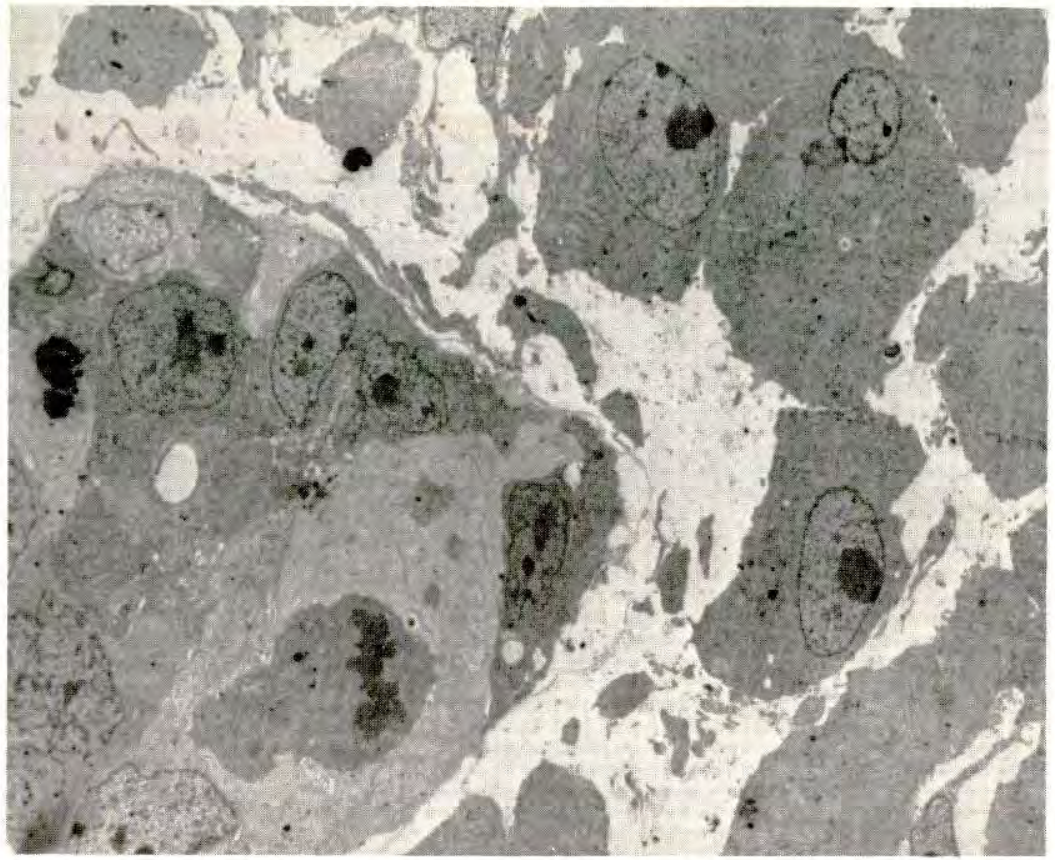

(b)

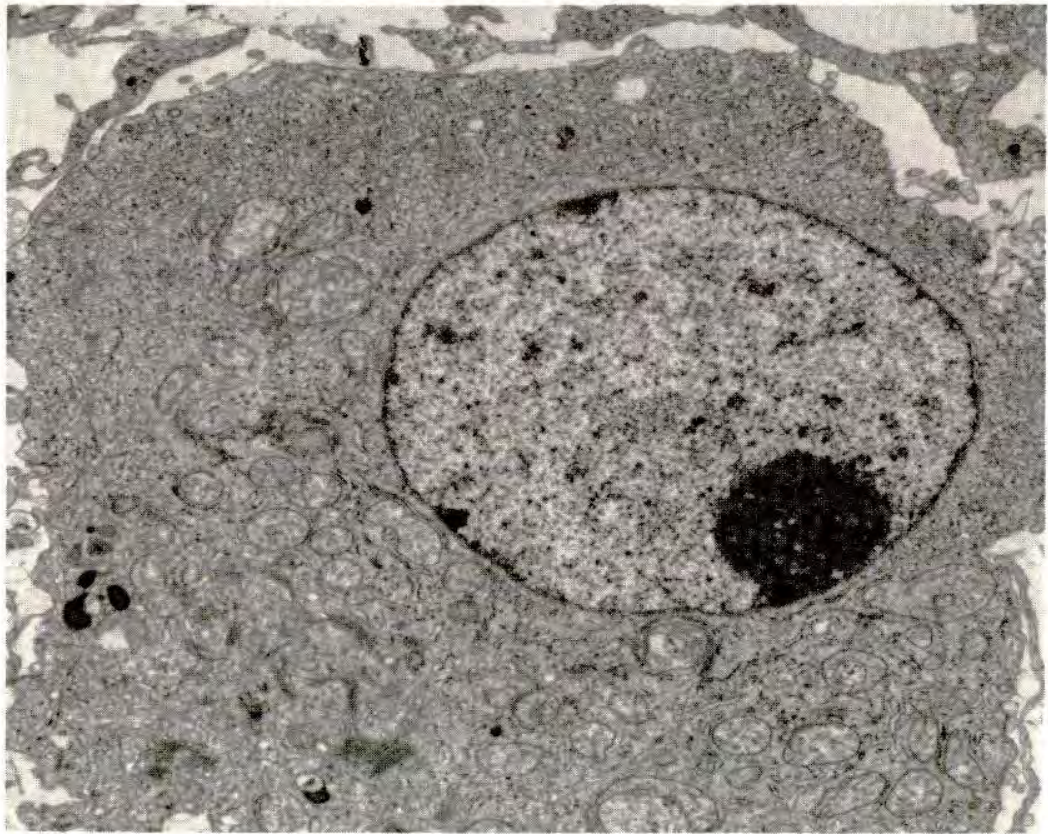

Figure 1.2(a) Testicular morphology at 35 days. To the left a sex cord is situated with a dividing germ cell. The peritubular space is empty; Leydig cells are well developed. (Magn. $2200 \times$ ). (b) Leydig cell with an oval nucleus and a prominent nucleolus, Large quantities of branched tubular SER. Long profile RER is coupled with mitochondria. The mitochondria display some degenerative forms. (Magn. $8500 \times$ ). By courtesy of Dr C.J.A.H.V. van Vorstenbosch 


\section{Sertoli cells}

Sertoli cells or sustentacular cells are characterized by a nucleus which is irregular in size and the mitochondria are elongated (Pelliniemi, 1975b). There is, however, very little information on Sertoli cell morphology in the foetal pig after 26 days post coitum.

\section{Germ cells}

The germ cells are recognized as large round cells having a large round nucleus with finely dispersed chromatin. At 27 days the germ cells are located singly within the testicular cords and are completely surrounded by Sertoli cells (Pelliniemi, 1975b). The number of germ cells in the testis of the foetal pig gradually increases by mitotic division from 42 days onwards (van Straaten and Wensing, 1977). They do not enter meiosis until the prepubertal period (Swierstra, 1968) whereas in female foetuses meiosis starts at about 40-48 days post coitum (Black and Erickson, 1968; Mauleon, 1978).

Two factors are involved in the onset of meiosis, Meiosis Inducing Substance (MIS) and Meiosis Preventing Substance (MPS). MIS in mammals is produced in the rete from mesonephric-derived cells both in the testis and the ovary. MPS which is produced within the testicular tissue (possibly within the testicular cords) might participate in preventing meiosis in the foetal testis (Byskov, 1979).

\section{Testicular hormones}

In the last ten years much information has become available on the biochemical aspects of testicular function. The testis already produces testosterone at an early stage and this steroid can be detected at about 26 days. Maximal testicular testosterone concentrations are found at about 35 days and decline thereafter (Raeside and Sigman, 1975). A comparable pattern of changes in testosterone secretion by the foetal pig testis has been observed in organ culture (Stewart and Raeside, 1976).

The biological activity of the androgens secreted by the foetal pig testis ( \pm 30 days) has been demonstrated in co-culture experiments with rat prostates (Moon, Hardy and Raeside, 1973). Concentrations of serum testosterone are higher $(\sim 4 \mathrm{ng} / \mathrm{ml})$ at 35 days (Ford, Christenson and Maurer, 1980) than in either the earlier or in the later part of the foetal period (Colenbrander, de Jong and Wensing, 1978; Ford, Christenson and Maurer, 1980). Although there is no doubt about androgen production in the testis, the location of androgen synthesis within the gonad is still uncertain. In adult gonads, androgens are produced by the Leydig cells. However, SER which is considered to be involved in steroid production (Christensen, 1975) could not be observed in 27-day old Leydig cells (Pelliniemi, 1975b). Enzyme histochemical activity of $\Delta^{5}-3 \beta$ hydroxysteroid dehydrogenase ( $3 \beta$-HSD) could not be detected in Leydig cells but only in the sex cords (Moon and Raeside, 1972). However, 
preliminary histochemical studies in our laboratory revealed $3 \beta$-HSD activity in Leydig cells around 35 days. Further histochemical studies at light and electronmicroscopical levels may solve the question of the site of androgen production in the early foetal period.

The onset of androgen production in the gonad is probably independent of gonadotrophic hormone stimulation. Testis differentiation and testosterone production occurs in organ culture in the absence of gonadotrophic hormones and hence is probably due to genetic programming of the steroid-producing cells. Human chorionic gonadotrophin (HCG) can stimulate testosterone production by the early foetal pig testis (Raeside and Middleton, 1979) but it remains questionable whether physiologically active extra-pituitary gonadotrophin-like compounds exist in the pig (Amoroso and Porter, 1970; Ziecik and Flint, 1980). Data on gonadotrophic hormone production by the foetal pituitary are scarce. At 55 days serum luteinizing hormone (LH) concentrations are below detectable levels even after stimulation with LH releasing hormone (Colenbrander et al., 1977; Colenbrander et al., 1980). Moreoever, foetal decapitation in the pig does not interfere with the morphological development of Leydig cells before 60 days (van Vorstenbosch, Colenbrander and Wensing, 1981). Thus, gonadotrophic hormone-dependent androgen secretion probably does not take place in the first phase of testicular development.

One other hormone produced by the testis of great significance for male sexual differentiation is the anti-Müllerian hormone (AMH). This protein is synthesized by foetal (and neonatal) Sertoli cells and mediates the regression of the Müllerian ducts (Jost, 1947; Blanchard and Josso, 1974). In the 27-day old pig foetus at the time of gonadal differentiation, AMH production is very low, but thereafter gradually increases. Total inhibition of rat Müllerian duct growth can be observed in co-cultures with 29 days pig testis after three days of culture (Tran, Meusy-Dessolle and Josso, 1977). The production of AMH by the Sertoli cells lasts until after birth (Tran, Meusy-Dessolle and Josso, 1981).

What is the effect of the testicular hormones on the extra-gonadal tissues? As already mentioned the AMH is responsible for the regression of the Müllerian ducts. The androgens produced by the testis are essential for the development of the male accessory sex organs and for the sexual differentiation of the brain. Development and differentiation of the male accessory sex glands and external genitalia follow testicular differentiation and are androgen-dependent. The sequence of development of somatic sex characteristics is fixed and often identical in different mammals (Jost, 1965; Price and Ortiz, 1965). Differentiation of the Wolffian duct and the anlage and development of the bulbo-urethral glands, prostate, seminal vesicles and the external genitalia occurs between 26 days, when androgen secretion starts, and 50 days (Koning, 1942; Zietschmann and Krölling, 1955; Gier and Marion, 1970). The anlage of the bulbo-urethral gland can be seen in the lateral wall of the urethral sinus at 30 days $(32 \mathrm{~mm})$. Development of the prostate can be observed in the lateral wall of the pelvic urethra after 40 days $(57 \mathrm{~mm})$. The seminal vesicles differentiate in connection with the Wolffian ducts after 50 days ( $88 \mathrm{~mm}$ ) (Koning, 1942).

Sexual differentiation of the brain, which in the adult male results in tonic gonadotrophic hormone secretion and male mating behaviour; is also 
androgen-dependent (Dörner, 1976). Exposure of female foetuses to exogenous testosterone earlier than 90 days leads to an impaired functioning of the stimulatory oestrogen feedback mechanism (Elsaesser and Parvizi, 1979). Testosterone treatment of neonatal females does not affect this feedback system (Colenbrander, 1978). This indicates that androgen secretion during the first phase of testicular development seems to be involved in brain sex priming. More information on sex differentiation of the brain and the role of the ovary in this process is discussed in Chapter 5 by Elsaesser.

Between 65 and 95 days testicular activity seems to be reduced. The testis/body weight ratio decreases, which means that testicular growth lags behind body growth (van Straaten and Wensing, 1977). Testosterone production by the Leydig cells (Colenbrander, de Jong and Wensing, 1978; Ford, Christenson and Maurer, 1980) is low. Sertoli cells probably still produce AMH as this hormone is present at 40 days and immediately after birth, but data on the period in between are lacking (Tran, Meusy-Dessolle and Josso, 1977; 1981). The number of germ cells in the testis gradually increases (van Straaten and Wensing, 1977), but refined data on the morophology of these cells in this period are also lacking.

Another aspect of male sexual development which occurs in this period of relative inactivity of the Leydig cells is the descent of the testis. An extra-abdominal position, resulting in a lower temperature of the gonad, is essential for spermatogenesis in adulthood. The process of descent is brought about by a swelling and subsequent regression of the extraabdominal part of the gubernaculum. This results in a movement of the testis towards the inguinal canal in the swelling phase and a descent into the scrotum during the regression phase (Wensing, 1968; Wensing, Colenbrander and van Straaten, 1980).

The process starts at approximately 60 days post coitum. The testis passes the inguinal canal at about 85 days and reaches the bottom of the scrotum shortly after birth. It has been postulated that gonadotrophic hormones regulate the process of descent (Hadziselimovic and Herzog, 1980). However, it is unlikely that gonadotrophic hormones are important as testicular descent in the decapitated foetus is undisturbed (Colenbrander et al., 1979). Testosterone is also unlikely to be an important regulating factor of gubernacular outgrowth, as in this period testosterone concentrations are low. In the decapitated foetus, where Leydig cell development is disturbed after 60 days, timing of the descent is normal (Colenbrander et al. , 1979). However testicular hormones still seem to play an essential role in this process as foetal castration at 60 days post coitum results in arrest of gubernaculum development and consequently no testicular descent occurs (Colenbrander, Macdonald and Elsaesser, unpublished observation). As the Leydig cells are rather undifferentiated after 55 days, a factor produced by the sex cords is probably involved in gubernacular outgrowth. Testosterone might be involved in the regression of the gubernaculum, which occurs after 85 days when serum testosterone concentrations are increasing (Colenbrander, de Jong and Wensing, 1978). Also in decapitated foetuses and neonatal pig freemartins which have very low testosterone concentrations, gubernacular regression is retarded (Colenbrander and Wensing, 1975; Colenbrander et al., 1979). 
After 90 days, when the testis has reached the neck of the scrotum, the second phase of testicular development starts.

\section{Perinatal period}

The second (perinatal) phase of testicular development extends from 90 days post coitum until three weeks after birth. In this period there is an increase in the testis/body weight ratio. Testis weight increases between 100 days post coitum and three weeks after birth, from $86 \mathrm{mg}$ to about $2 \mathrm{~g}$ in Landrace pigs (van Straaten and Wensing, 1977). This is mainly due to Leydig cell differentiation and proliferation.

\section{Leydig cells}

At three weeks after birth when the Leydig cells are maximally developed, they form almost $65 \%$ of the testicular volume. Two types of Leydig cells can be distinguished in the early postnatal period (van Straaten and Wensing, 1978). The intertubular cells are the first to be formed and are located between groups of coiled sex cords. They are already present, although less differentiated, in the early foetal period. The second type, the peritubular cells, are enclosed within the coils of the sex cords. They probably differentiate from peritubular mesenchymal elements (Moon and Hardy, 1973; Dierichs, Wrobel and Schilling, 1973) (Figure 1.3(a)). Apart from total Leydig cell volume, the cell nuclear size, cell volume and other histological features mark the differentiation of the interstitial cells (Dierichs, Wrobel and Schilling, 1973; van Straaten and Wensing, 1977). NADH-diaphorase and hydroxysteroid dehydrogenase (HSD) activity, as demonstrated histochemically (Figures 1.3(b) and 1.5), is intense in the second postnatal week and declines thereafter (Moon and Raeside, 1972; van Straaten and Wensing, 1978). The histochemical activity is most prominent in the intertubular Leydig cells whereas the peritubular cells show less HSD activity. The perinatal Leydig cells are surrounded by a basement membrane and cell connections appear as gap junctions and desmosome-like structures. There is an increase in the number of mitochondria with tubular cristae and electron dense inclusions. The smooth endoplasmic reticulum is abundant and consists of branched tubular and extensive whirls of SER; the latter may be fenestrated and microfilaments diminish sharply around birth. The RER is quantitatively unimportant (Figures 1.4(a) and (b)) (Dierichs, Wrobel and Schilling, 1973; van Vorstenbosch, Colenbrander and Wensing, 1981). Leydig cell development in the late foetal and postnatal period is dependent upon gonadotrophic hormones (Morat, 1977; Colenbrander et al., 1979).

After one month, regression of interstitial cells occurs and degeneration of mitochondria and dilatation of the cisternae of the smooth endoplasmic reticulum is observed. Leydig cell regression in this period even results in a decrease of the testis weight. 
(a)

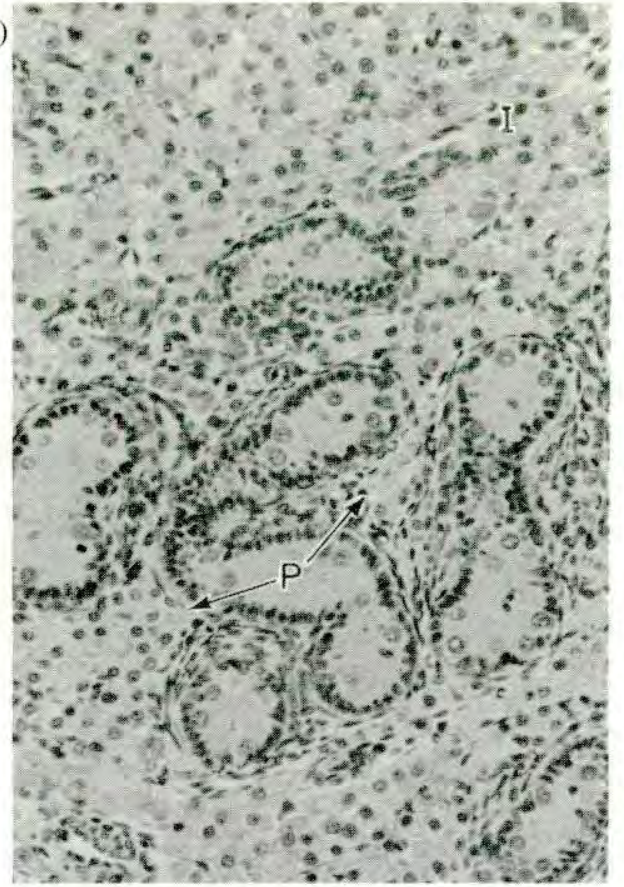

(c)

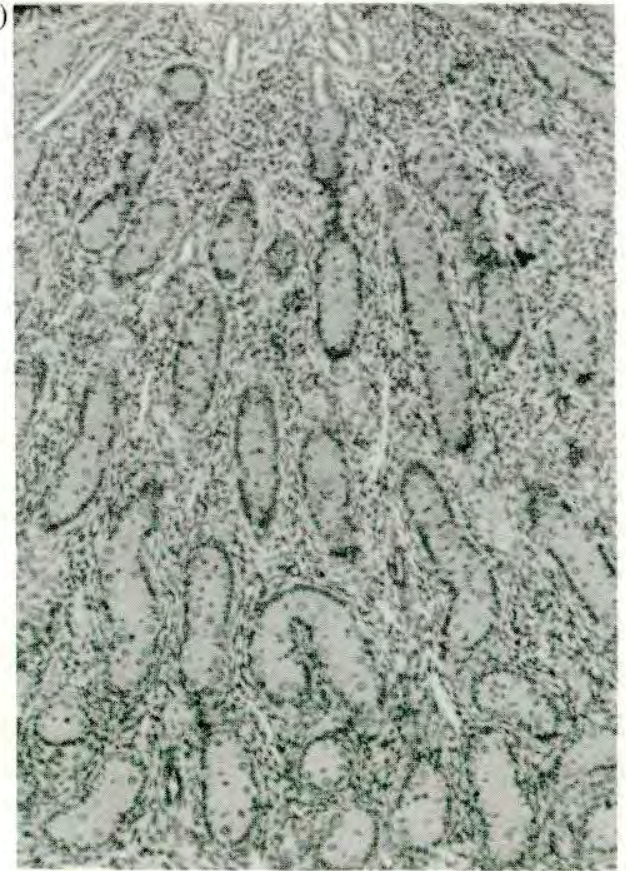

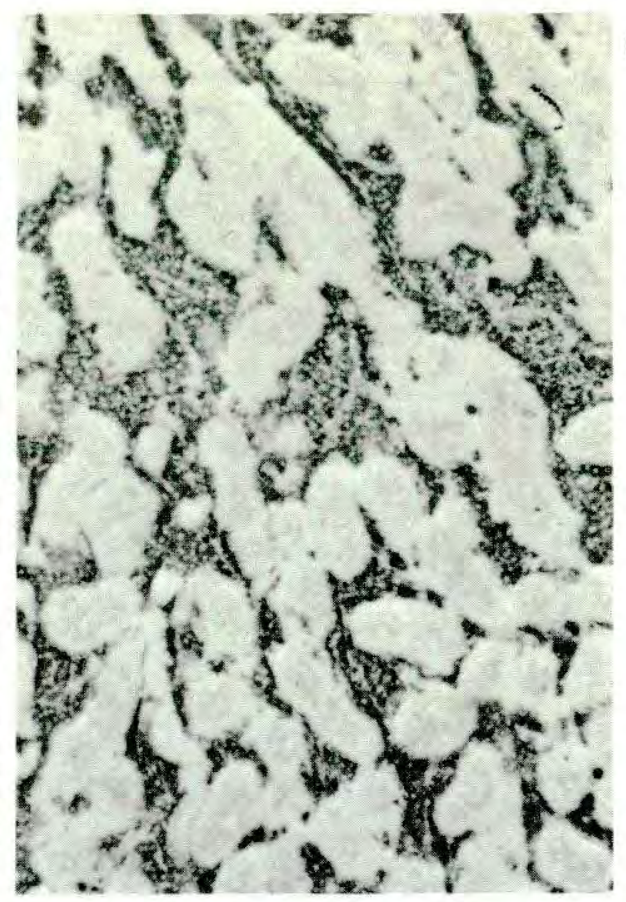

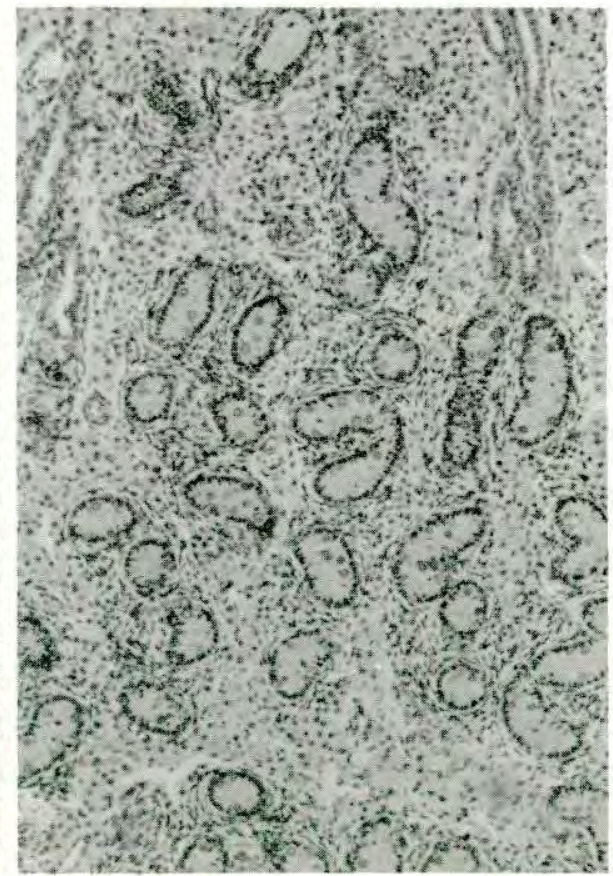

(d)

Figure 1.3 (a) Intertubular (I) and peritubular (P) Leydig cells 113 days post coitum (Bouin fixed, trichrome stained). (Magn. 189 $\times$ ). (b) NADH diaphorase activity of Leydig cells, 113 days post coitum. (Magn. 75×). (c)-(d) Coiling of the sex cord during development, 85 and 113 days post coitum respectively. (Bouin fixed, trichrome stained). (Magn. 96×). 
(a)

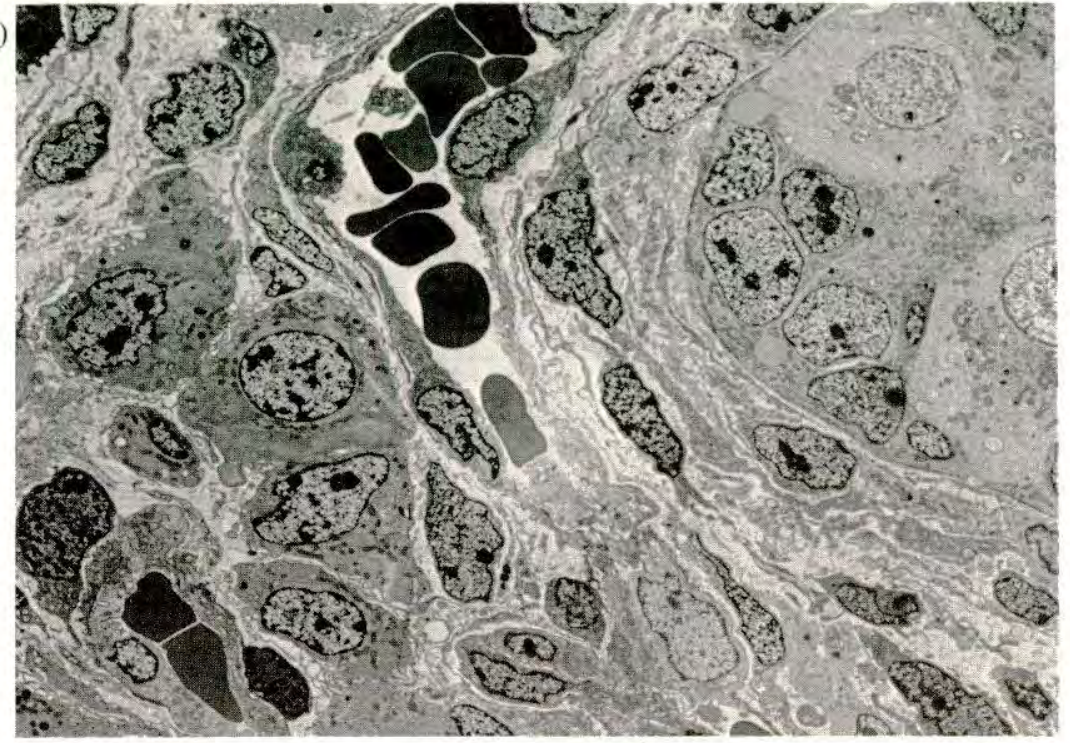

(b)
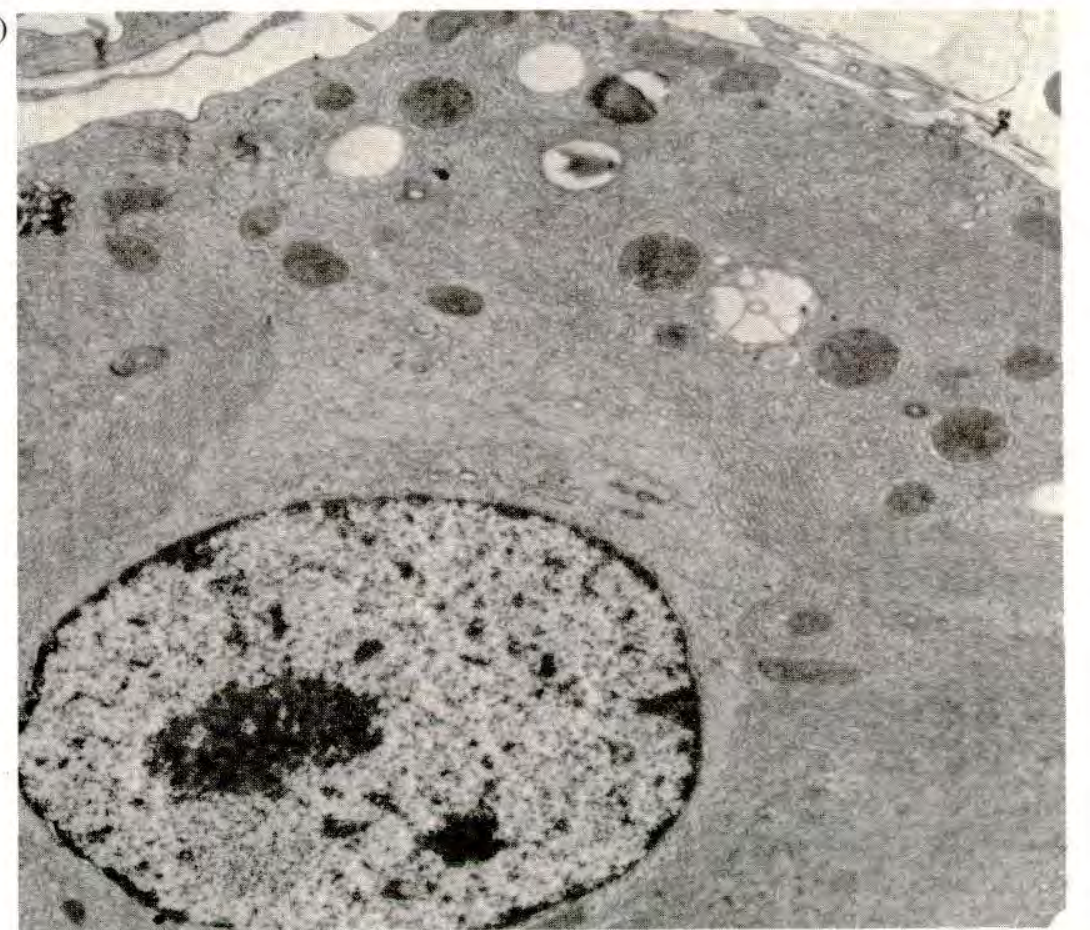

Figure 1.4(a) Testicular morphology at 113 days. To the right a sex cord is situated with germ cells, and Sertoli cells with lipid droplets. Several layers of mesenchymal cells surround the sex cord. To the left differentiated Leydig cells are located. (Magn. 1600×). (b) The Leydig cells contain conspicuous smooth endoplasmic reticulum (SER) mainly displayed in the form of whirls. Branched tubular SER is persistent in appreciable amounts. Near to the nucleus $10 \mathrm{~nm}$ microfilaments are present. (Magn. 10800×). By courtesy of Dr C.J.A.H.V. van Vorstenbosch 


\section{Sertoli cells}

Data on the development of Sertoli cells in the second half of the foetal period are scarce although they are the main component of the sex cords (or seminiferous tubules). The diameter of the seminiferous tubules is about $60 \mu \mathrm{m}$ and only increases after germ cell differentiation starts. However, tubular length increases markedly after 90 days post coitum (van Straaten and Wensing, 1977). The tubules which at first are rather straight, develop a coiled appearance in the perinatal period (Figure 1.3(c) and $(d)$ ). Four weeks after birth the rate of tubular length growth decreases again (van Straaten and Wensing, 1977). The mitotic activity of Sertoli cells which is high in the first month, then also decreases (Tran, Meusy-Dessolle and Josso, 1981). The blood testis barrier is still not formed at this age. At six weeks the Sertoli cells morphologically form a monomorphic cell population. They are juxtaposed on the internal edge of the seminiferous cords and on the apical side of the cells numerous extensions can be observed. The cytoplasm contains abundant SER and numerous ribosomes (Dierichs and Wrobel, 1975; Wrobel and Dierichs, 1975; Chevalier, 1978).

\section{Germ cells}

The number of germ cells per testis increases gradually in the late foetal and neonatal period. It does not seem to be influenced by the perinatal Leydig cell differentiation although there is a reduction in increase after four weeks after birth (van Straaten and Wensing, 1977). Germ cells (gonocytes) are morphologically characterized by a regular, round to oval shape and a centrally located nucleus. Concentration of cytoplasmic organelles is sparse in comparison with the Sertoli cells.

\section{Testicular hormones}

The differentiation of the testis in the perinatal period is also accompanied by an increase in steroid production. Serum testosterone concentrations which are relatively low $(<0.5 \mathrm{ng} / \mathrm{ml})$ in the second half of the foetal period rise perinatally and are maximal $(\sim 1.5 \mathrm{ng} / \mathrm{ml})$ in the second week after birth (Meusy-Dessolle, 1974; 1975; Colenbrander, de Jong and Wensing, 1978; Ford, Christenson and Maurer, 1980) (Figure 1.5). This rise and decline in serum testosterone concentrations runs parallel to a similar change in testicular androgen concentration (Booth, 1975; Segal and Raeside, 1975). However, not only quantitative changes but also important qualitative changes occur. Testosterone which is the main androgen in the foetal and early neonatal period is quantitatively much less important after six weeks than, for example, androstenediol and dehydroepiandrosterone (Ruokonen and Vihko, 1974; Booth, 1975).

Less is known about hormone production by the neonatal Sertoli cell. Hormones produced by the Sertoli cells are inhibin, AMH (anti-Müllerian hormone), oestradiol and MPS (meiosis preventing substance). The presence of MPS in Sertoli cells is still hypothetical and further study will be 

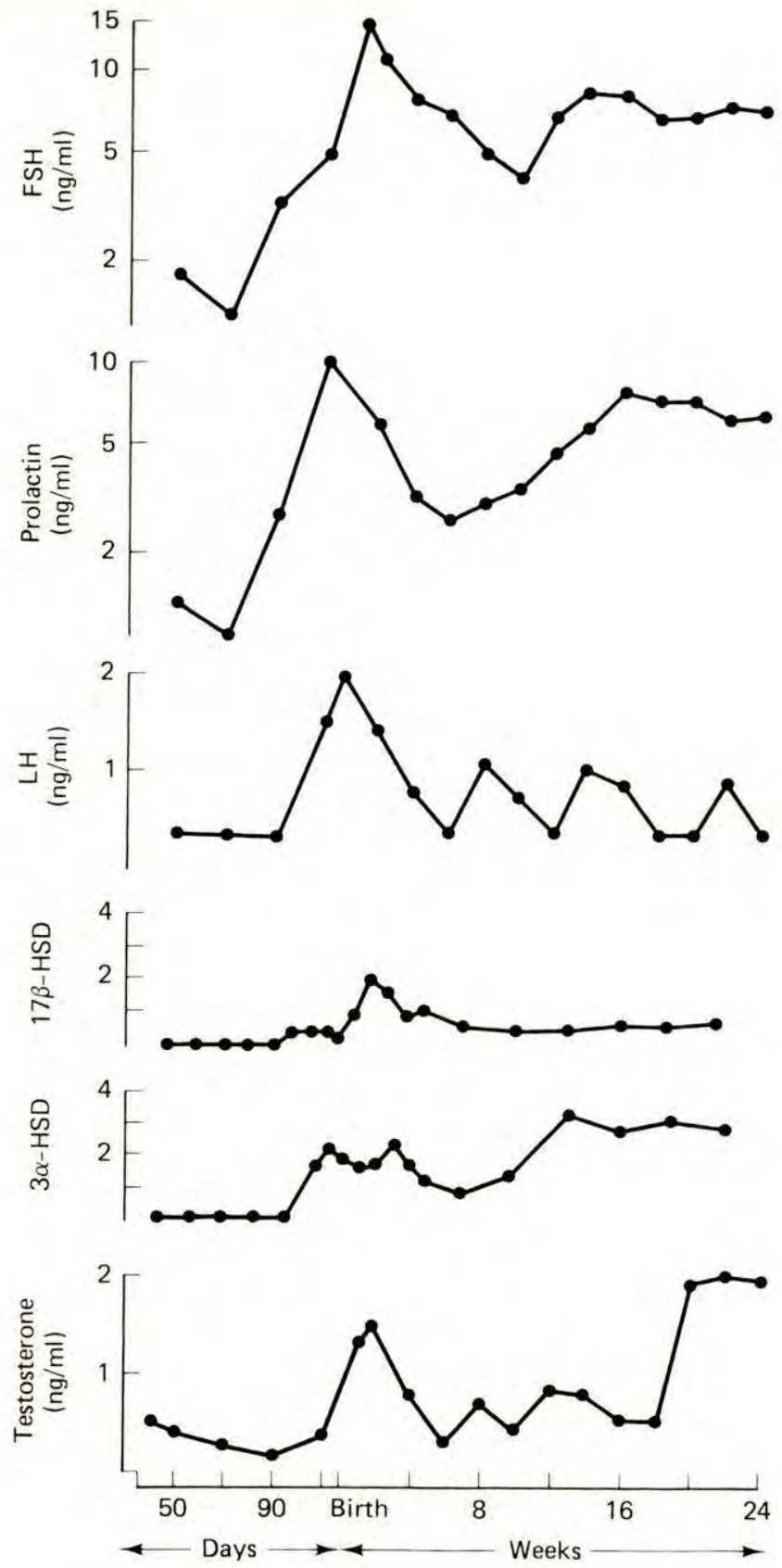

Figure 1.5 Changes in serum pituitary hormone concentrations, histochemical activity of the Leydig cells and serum testosterone concentrations during development. From Colenbrander and van der Wiel, unpublished observations, Colenbrander et al., 1977; van Straaten and Wensing 1978; Colenbrander, de Jong and Wensing, 1978 
needed to clarify this topic. Also no data are available in the male pig on inhibin, a non-androgenic hormone produced by the Sertoli cells, which has been demonstrated in porcine follicular fluid (Welschen et al., 1977; Steinberger, 1979). This polypeptide plays a significant role in the feedback control by the testis of FSH production by the pituitary (Setchell, 1978; de Jong et al., 1979) and may be responsible for a decline in serum FSH concentrations in the male pig 3-4 weeks after birth (see below).

$\mathrm{AMH}$, which is already produced at 27 days, is still present in the postnatal period, although it could not be detected in the first few days of postnatal life. In the second week after birth AMH activity increases to a high level similar to that observed in the late foetal period; thereafter it slowly decreases and practically disappears after 70 days (Tran, MeusyDessolle and Josso, 1981). Oestradiol ( $\left.\mathrm{E}_{2}\right)$ is produced by the Sertoli cell, from steroid precursors produced in the Leydig cell (Dorrington and Armstrong, 1975) but may also be produced by the Leydig cell itself (Rommerts and Brinkmann, 1981). Serum $\mathrm{E}_{2}$ concentrations are very high $(1.1 \pm 0.3 \mathrm{ng} / \mathrm{ml})$ in the late foetal period due to placental production (Bowerman, Anderson and Melampy, 1964; Macdonald et al., 1979), but rather low $(<0.2 \mathrm{ng} / \mathrm{ml})$ in the neonatal and prepubertal animal. $\mathrm{E}_{2}$ plays an important role in male sexual development in the boar. It is known to suppress Leydig cell function by decreasing the activities of $17 \beta$ hydroxylase (Brinkmann et al., 1980), but also in the pig it stimulates the accessory sex glands and male sexual behaviour (Joshi and Raeside, 1973).

The protein binding of steroids has not been studied extensively but the binding of progesterone increases from $83 \%$ to $92 \%$ between 57 and 111 days (Macdonald et al., 1980).

\section{Pituitary}

Pituitary hormones which are important for gonadal development are luteinizing hormone ( $\mathrm{LH})$, follicle stimulating hormone (FSH) and prolactin.

Morphological studies of the pituitary indicate that growth hormoneproducing cells are already differentiated at 46 days and thyroid stimulating hormone (TSH)- and FSH-producing cells at 70-76 days (Liwska, 1975; 1978). Preliminary results of immunohistochemical staining for prolactin show that at 70 days, only very few cells $(1.2 \pm 0.6 \%)$ stain positively; at the end of gestation many more cells $(8.7 \pm 0.8 \%)$ show a positive reaction (Colenbrander et al., 1982). A comparable staining pattern has been observed for LH-producing cells (Meyer, personal communication). Higher amounts of LH and FSH are detectable in the pituitary at the end of gestation when compared with younger ages (Melampy et al., 1966).

Serum LH concentrations rise at the end of gestation, are high in the second week after birth and decline thereafter (Figure 1.5). The increase of serum $\mathrm{LH}$ in the foetus can be mimicked at an earlier stage by injecting $\mathrm{LH}$ releasing hormone, which does not raise $\mathrm{LH}$ levels at 50 days, induces a positive, mediocre response in some foetuses at 70 days but produces a marked increase in all foetuses at 110 days (Colenbrander et al., 1980).

So, in the neonatal period LH concentrations rise and induce a parallel rise in testosterone. No feedback exists in the first weeks after birth, as 
castration does not result in increased LH levels (Ford and Schanbacher, 1977). However, when the animal is castrated at eight weeks, LH concentrations rise (Colenbrander et al., 1977) suggesting that the feedback is probably established in the third week, when both LH and testosterone decline in control animals (Figure 1.5).

FSH and prolactin concentrations are rather low before 90 days post coitum. They gradually rise to maximal values around birth when the serum concentrations are $14.0 \pm 0.7 \mathrm{ng} / \mathrm{ml}$ and $10.1 \pm 1.2 \mathrm{ng} / \mathrm{ml}$ respectively; thereafter concentrations of both hormones decline (Colenbrander, van de Wiel and Wensing, 1980; Colenbrander et al., 1982) (Figure 1.5). FSH is essential for the initiation of spermatogenesis in puberty via stimulation of Sertoli cells. It also induces an increase in androgen binding protein (ABP) production by Sertoli cells (Steinberger, 1971). There are clear indications that prolactin plays a crucial role in testicular function. Absence of prolactin in mice leads to gonadal atrophy or underdevelopment of the gonad. High concentrations of prolactin also result in sterility (Bartke et al., 1978).

\section{Pubertal period}

After the second period of Leydig cell differentiation and regression, the final phase of testicular development gradually approaches. At three months the testis/body weight ratio increases again, mainly due to tubular development. This is not caused by Sertoli cell multiplication, as the mitotic activity of these cells has declined after 30 days (Tran, MeusyDessolle and Josso, 1981), but to the spectacular increase in the number of germ cells (van Straaten and Wensing, 1977). The Leydig cells differentiate again and increase in number after 2.5 months.

\section{Leydig cells}

After 13 weeks the Leydig cells which are enclosed by tubuli (peritubular) differentiate and maximal development is reached at about four months of age. Morphologically the Leydig cells have much in common with the perinatally differentiated Leydig cells. The SER, characteristic for steroidproducing cells, is present in large quantities and the mitochondria contain closely packed tubules. Between adjacent cells membrane fusions can be observed (Belt and Cavazos, 1967; Dierichs, Wrobel and Schilling, 1973). HSD activity increases in the third month (van Straaten and Wensing, 1978) (Figure 1.5) and the peritubular cells show marked $3 \alpha$-HSD and $17 \beta$-HSD activity. The intertubular cells remain small and are histochemically inactive (van Straaten and Wensing, 1978). Also in other species different populations of Leydig cells are present in the testis (Rommerts and Brinkmann, 1981) and this may be due to a difference in location. Some are located in close proximity to Sertoli cells which can influence Leydig cells by specific secretion products (Aoki and Fawcett, 1978). Others are in close contact with lymph fluid or blood vessels (Fawcett, Neaves and Flores, 1973). In the fourth month androgen concentrations in 
the testis increase again. Testosterone, however, is quantitatively unimportant and the main steroids present are 16-androstenes (Ruokonen and Vihko, 1974; Booth, 1975; Gray et al., 1971; Colenbrander, de Jong and Wensing, 1978; Florcruz and Lapwood, 1978).

\section{Sertoli cells}

Sertoli cell development slowly progresses after birth. Mitotic activity decreases after 30 days, Sertoli cell junctions appear at six weeks and the blood testis barrier is formed around 100 days and completed after 120 days (Tran, Meusy-Dessole and Josso, 1981).

In the mature testis two types of Sertoli cells characterized by the presence of a large lipid droplet are present. Sertoli cells with a light nucleus extend from the basement membrane to the lumen of the tubule and show the same fine structure as those in other mammalian species, i.e. numerous filaments and ribosomes, abundant SER and typical junctions with adjacent Sertoli cells and with germ cells. The second type of Sertoli cell has a dark nucleus and is found only in the basement region of the seminiferous epithelium. These cells contain a limited cytoplasm which contains SER and numerous filaments (Chevalier, 1978). The Sertoli cell structure and function is hormonally controlled by FSH and androgens (Hansson et al., 1975; Chevalier, 1979); however their functional activity also seems to be partly regulated by the germ cells. In the rat protein synthesis and secretion by the Sertoli cells is influenced by the stage of development of the spermatids that surround the Sertoli cells (Ritzen and Boctani, 1981).

\section{Germ cells}

Spermatogenesis is initiated during the pubertal development of the testis. In the perinatal period only undifferentiated germ cells (gonocytes) are present; at 10 weeks after birth differentiation of germ cells can be observed (van Straaten and Wensing, 1977) and at three months spermatogonia and pachytene spermatocytes are present and sometimes round spermatids (stage 1-8) can also be found. After four months spermatogenesis is completed in many seminiferous tubules.

The whole spermatogenic cycle takes 8.6 days (Swierstra, 1968). The kinetics of the spermatogenic epithelium in the adult boar have been studied in whole mounts of the seminiferous tubules (Frankenhuis, de Rooy and Kramer, 1980), thus enabling spermatogonia and spermatogonial divisions to be identified. Spermatid development is comparable with spermatid development in small laboratory rodents and can be subdivided into 16 steps, characterized by changes in the development of the acrosome or the shape of the nucleus of the spermatids (Table 1.1). Four classes of spermatogonia can be distinguished:

(a) Undifferentiated $A$ spermatogonia $\left[A\right.$ single $\left(A_{s}\right)$, A paired $\left(A_{p r}\right), A$ aligned $\left.\left(\mathrm{A}_{\mathrm{al}}\right)\right]$

(b) Differentiated A spermatogonia $\left[\mathrm{A}_{1}, \mathrm{~A}_{2}, \mathrm{~A}_{3}, \mathrm{~A}_{4}\right]$; 
Table 1.1 CELL ASSOCIATION IN EACH OF THE TWELVE STAGES OF THE CYCLE OF THE BOAR SEMINIFEROUS EPITHELIUM

\begin{tabular}{llllllllllll}
\hline 13 & 14 & 14 & 15 & 15 & 15 & 16 & 16 & & & & \\
1 & 2 & 3 & 4 & 5 & 6 & 7 & 8 & 9 & 10 & 11 & 12 \\
$\mathrm{P}$ & $\mathrm{P}$ & $\mathrm{P}$ & $\mathrm{P}$ & $\mathrm{P}$ & $\mathrm{P}$ & $\mathrm{P}$ & $\mathrm{P}$ & $\mathrm{P}$ & $\mathrm{P}$ & $\mathrm{D}$ & $\mathrm{M}_{1}$ \\
$\mathrm{~A}_{3} / \mathrm{A}_{4}$ & $\mathrm{~A}_{4} / \mathrm{In}$ & $\mathrm{In}$ & $\mathrm{In} / \mathrm{B}$ & $\mathrm{B}$ & $\mathrm{B} / \mathrm{PLS}$ & $\mathrm{PLS}$ & $\mathrm{L}$ & $\mathrm{L}$ & $\mathrm{Z}$ & $\mathrm{Z}$ & $\mathrm{P}$ \\
& & $\mathrm{A}_{1}$ & $\mathrm{~A}_{1}$ & $\mathrm{~A}_{1}$ & $\mathrm{~A}_{1}$ & $\mathrm{~A}_{1}$ & $\mathrm{~A}_{1}$ & $\mathrm{~A}_{1} / \mathrm{A}_{2}$ & $\mathrm{~A}_{2}$ & $\mathrm{~A}_{2} / \mathrm{A}_{3}$ & $\mathrm{~A}_{3}$
\end{tabular}

Undifferentiated type $\mathrm{A}$ spermatogonia $\left(\mathrm{A}_{\mathrm{s}}, \mathrm{A}_{\mathrm{pr}}, \mathrm{A}_{\mathrm{al}}\right)$

Each column consists of the various cell types making a cellular association. These associations succeed one another from left to right in the table. $A_{s}, A_{p r}, A_{a l}, A_{1}, A_{2}, A_{3}$ and $A_{4}$ : spermatogonia type $A$; In: intermediate type spermatogonia; B: spermatogonia type B; PLS: preleptotene spermatocytes; L: leptotene; $\mathrm{Z}$ : zygotene; $\mathrm{P}$ : pachytene; $\mathrm{D}$ : diplotene and diakinesis; $\mathrm{M}_{1}$ : first meiotic division; $\mathrm{M}_{2}$ : second meiotic devision; 1-16: steps in spermatid development.
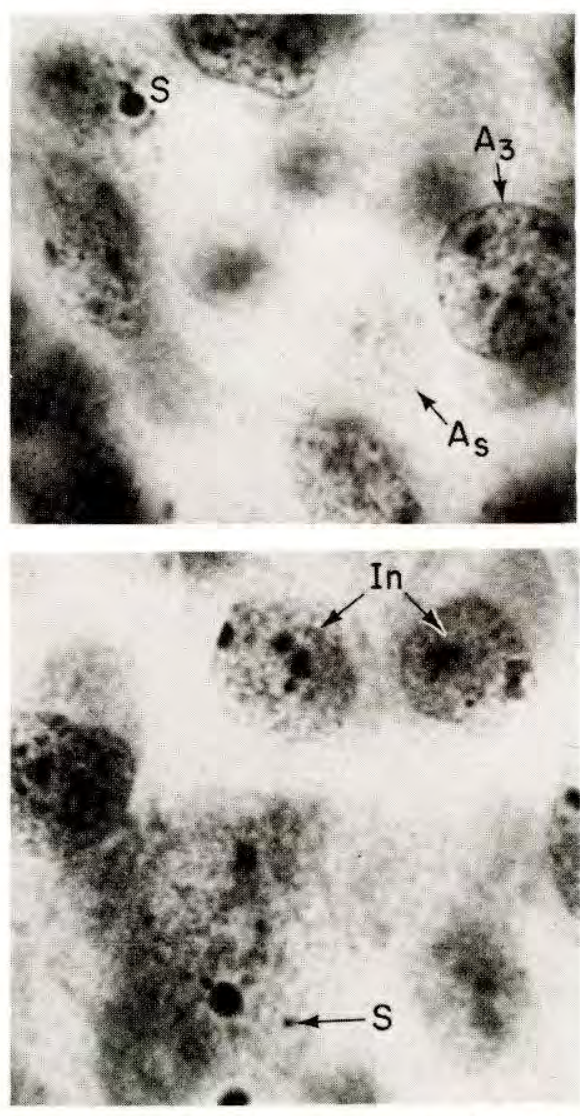

Figure 1.6 Whole mounted seminiferous tubules in the plane of focus where Sertoli cells, spermatogonia and preleptotene spermatocytes occur i.e. just under the basement membrane. The tubules were fixed in Zenker for 24 hours and stained with Harris' hemalum to identify spermatogonia and spermatogonial divisions. $S$ : Sertoli cell; $A_{5}, A_{1}, A_{3}$ : spermatogonia type $\mathrm{A}$; $\mathrm{B}$ : spermatogonia type $\mathrm{B}$; In: intermediate type spermatogonia; PLS: preleptotene spermatocyte. (Magn. 1640×) 
(c) Intermediate spermatogonia (In); and

(d) B spermatogonia (B) (Figure 1.6).

Undifferentiated A spermatogonia can be identified most easily in those parts of the tubules where other types of spermatogonia are in their $G_{2}$ phase, as their cell cycle is not in phase with the cell cycle of the differentiated $\mathrm{A}$ and intermediate spermatogonia.

In all probability the A single spermatogonia are to be regarded as the stem cells of spermatogenesis. When in this model of spermatogonial stem cell renewal an A single spermatogonium divides, it gives rise to two A paired spermatogonia, that either stick together and by the second division form A aligned spermatogonia, or migrate away from each other to become two new A single spermatogonia. The $\mathrm{A}_{1}$ spermatogonia, the first of the differentiated A spermatogonia, arise from A aligned spermatogonia. Along the length of the tubules four waves of divisions of $A$ spermatogonia can be subdivided into four generations $\left(A_{1}, A_{2}, A_{3}, A_{4}\right)$. The last of these waves gives rise to intermediate spermatogonia (In), intermediate between A and B spermatogonia with respect to the amount of chromatin in the nucleus. Intermediate spermatogonia divide into type B spermatogonia and these into preleptotene spermatocytes. Thereafter the prophase of the first meiotic division starts, followed by the second meiotic division. By studying whole mounts of the seminiferous tubules it has become clear that the kinetics of the spermatogenic epithelium in the boar demonstrates a striking similarity with that in small laboratory rodents.

During testicular differentiation, which is paralleled by increased androgen secretion, the accessory sex glands also differentiate. Their weight markedly increases in the later part of puberty (Egbunike, 1979) as well as their histochemical activity (Aitken, 1960; Wrobel and Fallenbacher, 1974). Hypophysectomy or castration results in underdevelopment of the accessory sex glands and a decrease in weight and histochemical activity can be observed (Wrobel, 1969; Morat et al., 1980).

The factors which determine the onset of puberty in the male still remain to be unravelled. Endocrinological changes, but also environmental factors are important (Ramaley, 1979; Egbunike, 1979). Serum concentrations of gonadotrophic hormones in the pig do not change remarkably in the pubertal period (Figure 1.5). However, minor changes in the balance of pituitary hormone concentrations i.e. LH, FSH, and prolactin, may play a decisive role. Another important event could be the formation of the blood testis barrier (Ramaley, 1979). Data are also scarce on the developmental pattern of gonadotrophic hormone and the steroid receptors of Leydig and Sertoli cells in the pig during development. Preliminary in vitro studies on the regulation of HCG receptors in the Leydig cells of immature pigs demonstrate that prostaglandin $F_{2 \alpha}$ induces a decrease in the number of HCG binding sites (Haour et al., 1981). Changes in the receptor population could probably also play a role in the onset of puberty.

\section{Conclusions}

In the pig three periods of testicular development can be distinguished. The first period is between 26 and 60 days of gestation, at the time of 
sexual differentiation. The second period occurs perinatally when the increase in testicular weight is mainly due to the increase in number of Leydig cells and their state of development. The third is during puberty when spermatogenesis starts.

Testicular development between 26 and 60 days is probably independent of gonadotrophic hormone stimulation. The Leydig cells are the most likely source of the early peak of serum testosterone, seen at 35 days. The second phase of Leydig cell development seems to be initiated by foetal pituitary activity. Rising gonadotrophic hormone concentrations in the peripheral circulation initiate Leydig cell differentiation which results in increased testicular androgen secretion. The significance of this perinatal Leydig cell differentiation is still unclear. After birth when a functional feedback system is established between the gonad and the hypothalamopituitary system, both gonadotrophic hormone and androgen concentrations in the peripheral circulation decline. The factors which are essential for the third period of Leydig cell differentiation are still unknown.

Sertoli cell development seems to be more continuous when compared to that of the Leydig cells. AMH, produced by the Sertoli cell, is already present at 27 days post coitum and can still be detected after birth. Just after birth elongation of the seminiferous tubules is temporarily enhanced, possibly due to high serum FSH concentrations which stimulate the Sertoli cell. No remarkable changes in gonadotrophic hormone concentrations occur between 100 and 120 days after birth when the blood testis barrier is formed.

From the early foetal period germ cell development does not seem, at least quantitatively, to be influenced by hormonal changes. The germ cells gradually increase in number by mitosis. Two months after birth differentiation of germ cells starts and meiosis occurs. At four months spermatid development is completed in many seminiferous tubules and kinetically shows a striking similarity to that in laboratory rodents. The factors which are involved in the onset of puberty still remain to be unravelled.

\section{References}

AITKEN, R.N. (1960). A histochemical study of the accessory genital glands of the boar. J. Anat. 94, 130-142

ALLEN, B.M. (1904). The embryonic development of the ovary and testis of the mammals. Am. J. Anat. 3, 89-146

AMOROSO, E.C. and PORTER, D.G. (1970). The endocrine functions of the placenta. In Scientific Foundations of Obstetrics and Gynaecology, (E.E. Phillip, J. Barnes, and M. Newton, Eds.), pp. 556-586. London, Heineman

ANCEL, P. and BOUIN, P. (1903). Histogenèse de la glande interstitiele du testicule chez le porc. C. r. Seanc. Soc. Biol. 55, 1680-1682

AOKI, A. and FAWCETT, D.W. (1978). Is there a local feedback from the seminiferous tubules affecting activity of the Leydig cells? Biol. Reprod. 19, 144-158

BARTKE, A., HAFIEZ, A.A., BEX, F.J. and DALTERIO, S. (1978). Hormonal interactions in regulation of androgen secretion. Biol. Reprod. 18, 44-54 
BELT, W.D. and CAVAZOS, L.F. (1967). Fine structure of the interstitial cells of Leydig in the boar. Anat. Rec. 158, 333-350

BLACK, J.L. and ERICKSON, B.H. (1968). Oogenesis and ovarian development in the prenatal pig. Anat. Rec. 161, 45-56

BLANCHARD, M.G. and JOSSO, N. (1974). Source of the Anti-Mullerian hormone synthesized by the fetal testis. Mullerian-inhibiting activity of fetal bovine Sertoli cells in tissue culture. Pediat. Res. 8, 968-971

BOOTH, W.D. (1975). Changes with age in the occurrence of $\mathrm{C}_{19}$ steroids in the testis and submaxillary gland of the boar. J. Reprod. Fert. 42, 459-472

BOWERMAN, A.M., ANDERSON, L.L. and MELAMPY, R.M. (1964). Uterinary estrogens in cycling, pregnant, ovariectomized and hysterectomized gilts. Lowa St. J. Sci. 38, 437-445

BRINKMANN, A.O., LEEMBORG, F.G., ROODNAT, E.M. DE JONG, F.H. and VAN DER MOLEN, H.J. (1980). A specific action of estradiol on enzymes involved in testicular steroidogenesis. Biol. Reprod. 23, 805-809

BYSKOV, A.G. (1979). Regulation of meiosis in mammals. Anns Biol. anim. Biochim. Biophys. 19, 1251-1261

CHEVALIER, M. (1978). Sertoli cell ultrastructure. I. A comparative study in immature, pubescent adult and cryptorchid pigs. Anns Biol. anim. Biochim. Biophys. 18, 1279-1292

CHEVALIER, M. (1979). Sertoli cell ultrastructure. II. Morphological effects of hypophysectomy in pubescent pigs. Anns Biol. anim. Biochim. Biophys. 19, 583-596

CHRISTENSEN, A.K. (1975). Leydig cells. In Handbook of Physiology; Section 7, Endocrinology; Vol. 5, Male Reproductive System, (R.O. Greep and E.B. Astwood, Eds), pp. 57-94. Baltimore, Waverley Press Inc.

COLENBRANDER, B. (1978). Aspects of sexual differentiation in the pig. Thesis, Utrecht

COLENBRANDER, B. and WENSING, C.J.G. (1975). Studies on phenotypically female pigs with ovarian aplasia and inguinal hernia. Proc. Koninklijke Nederlandse Akademie $v$. Wetenschap C78, 33-46

COLENBRANDER, B., DE JONG, F.H. and WENSING, C.J.G. (1978). Changes in serum testosterone concentrations in the male pig during development. J. Reprod. Fert. 53, 377-380

COLENBRANDER, B., VAN DE WIEL, D.F.M. and WENSING, C.J.G. (1980). Changes in serum FSH concentrations during fetal and prepubertal development in pigs. Proc. VI Int. Congr. Endocrinology, Melbourne, 228 (Abstract)

COLENBRANDER, B., KRUIP, Th.A.M., DIELEMAN, S.J. and WENSING, C.J.G. (1977). Changes in serum LH concentrations during normal and abnormal sexual development in the pig. Biol. Reprod. 17, 506-513

COLENBRANDER, B., MACDONALD, A.A., PARVIZI, N. and ELSAESSER, F. (1980). Changing responsiveness of fetal pig pituitary to LH-RH. Proc. Int. Union Physiol. Sci. Budapest Vol. XIV, p. 1106 (Abstract)

COLENBRANDER, B., ROSSUM-KOK, C.M.J.E. van, STRAATEN, H.W.M. van, and WENSING, C.J.G. (1979). The effect of fetal decapitation on the testis and other endocrine organs in the pig. Biol. Reprod. 20, 198-204

COLENBRANDER, B., MACDONALD, A.A., MEIJER, J.C., ELLENDORFF, F., VAN DE WIEL, D.F.M. and BEVER, M.M. (1982). Prolactin in the pig fetus (Abstract). Eur. J. Obstet. Gynaec. Reprod. Biol., in press. 
DE JONG, F.H., WELSCHEN, R., HERMANS, W.P., SMITH, S.D. and VAN DER MOLEN, H.J. (1979). Inhibin, follicular fluid and Sertoli cell medium. $J$. Reprod. Fert., Suppl. 26, 47-59

DIERICHS, R., and WROBEL, K.H. (1975). Membranspezialisierungen bei Sertolizellen des Schweines. Verh. anat. Ges. 69, 845-847

DIERICHS, R., WROBEL, K.H. and SCHILLING, E. (1973). Licht-, und Elektronenmikroskopische Untersuchungen an den Leydigzellen des Schweines während der postnatalen Entwicklung. Z. Zellforsch. mikrosk. Anat. 143, 207-227

DORRINGTON, J.H. and ARMSTRONG, D.T. (1975). FSH stimulates estradiol$17 \beta$ synthesis in cultured Sertoli cells. Proc. natn. Acad. Sci. USA 72, 2677-2681

DORNER, G. (1976). Sex hormone-dependent differentiation processes. In Hormones and Brain Differentiation, pp. 94-127. Amsterdam, Elsevier

EGBUNIKE, G.N. (1979). Development of puberty in Large White boars in a humid tropical environment. Acta Anat. 104, 400-405

ELSAESSER, F. and PARVIZI, N. (1979). Estrogen feedback in the pig. Sexual differentiation and the effect of prenatal testosterone treatment. Biol. Reprod. 20, 1187-1193

FAWCETT, D.W., NEAVES, W.B. and Flores, M.N. (1973). Comparative observations on intertubular lymphatics and the organization of the interstitial tissue of the mammalian testis. Biol. Reprod. 9, 500-532

FLORCRUZ, S.V. and LAPWOOD, K.R. (1978). A longitudinal study of pubertal development in boars. Int. J. Androl. 1, 317-330

FORD, J.J. and SCHANBACHER, B.D. (1977). Luteinizing hormone secretion and female Indosis behaviour in male pigs. Endocrinology 100, 10331038

FORD, J.J., CHRISTENSON, R.K. and MAURER, R.R. (1980). Serum testosterone concentrations in embryonic and fetal pigs during sexual differentiation. Biol. Reprod. 23, 583-587

FRANKENHUIS, M.T., DE ROOY, D.G. and KRAMER, M.F. ((1980). Spermatogenesis in the pig. In Proc. 9th Int. Congr. Anim. Reprod. A.l., Madrid, 265

GIER, H.T. and MARION, G.B. (1970). Development of mammalian testes and genital ducts. Biol. Reprod. Suppl. 1, 1-23

GRAY, R.C., DAY, B.N., LASLEY, J.F. and TRIBBLE, F. (1971). Testosterone levels of boars at various ages. J. Anim. Sci. 33, 124-126

HADZISELIMOVIC, F. and HERZOG, B. (1980). Etiology of testicular descent. In Descended and Cryptorchid Testis, (E.S.E. Hafez, Ed.), pp. 138-147. The Hague, Nijhoff

HANSSON, V., WEDDINGTON, S.C., NAESS, O. and ATTRAMADAL, A. (1975). Testicular androgen binding protein (ABP) - A parameter of Sertoli cell secretory function. In Hormonal Control of Spermatogenesis, (F.S. French, V. Hansson, E.M. Ritzen and S. Nayfeh, Eds.) pp. 323-336. New York, Plenum Press

HAOUR, F., MATHER, J., DRAY, F. and SAEZ, J.M. (1981). Regulation of HCG receptors by gonadotrophin in porcine Leydig cells. Int. J. Androl. (Abstract), in press

JIRASEK, J.E. (1976). Principles of reproductive embryology. In Disorders of Sexual Differentiation, (J.L. Simpson, Ed.), pp. 51-110. New York, Academic Press 
JOSHI, H. and RAESIDE, J.I. (1973). Synergistic effects of testosterone and oestrogens on accessory sex glands and sexual-behaviour of the boar. $J$. Reprod. Fert. 33, 411-423

JOST, A. (1947). Recherches sur la differenciation sexuelle de l'embryon de lapin. 3. Role des gonades foetales dans la differenciation sexuelle somatique. Archs. Anat. microsc. Morph. exp. 36, 271-315

JOST, A. (1965). Gonadal hormones in the sex differentiation of the mammalian fetus. In Organogenesis, (R.L. de Haan and H. Ursprung, Eds.), pp. 611-628. New York, Holt, Rinehart and Winston

KONING, J.N. (1942). Over de ontwikkeling van den sinus urogenitalis en de accessoire geslachtsklieren van het varken. Thesis, Utrecht

LIN, C.C., BIEDERMAN, B.M., JAMRO, H.K., HAWTHORNE, A.B. and CHURCH, R.B. (1980). Porcine chromosome identification and suggested nomenclature. Can. J. Genet. Cytol. 22, 103-116

LIWSKA, J. (1975). Development of the adenohypophysis in the embryo of the domestic pig. Folia morph. 34, 211-217

LIWSKA. J. (1978). Ultrastructure of the adenohypophysis in the domestic pig. Part I: Cells of the pars anterior. Folia Histochem. Cytochem. 16, 307-314

MACDONALD, A.A., COLENBRANDER, B., ELSAESSER, F. and HEILHECKER, A. (1980). Progesterone production by the pig fetus and the response to stimulation by adreno-corticotrophin. $J$. Endocr. 85, 34-35P

MACDONALD, A.A., ELSAESSER, F., PARVIZI, N., HEILHECKER, A., SMIDT, D. and ELLENDORFF, F. (1979). Progesterone, oestradiol $17 \beta$ and luteinizing hormone concentrations in blood and amniotic fluid of chronically catheterised pig fetuses. J. Endocr. 80, 14P

MAULEON, P. (1978). Ovarian development in young mammals. In Control of Ovulation, (D.B. Crighton, N.B. Haynes, G.R. Foxcroft and G.E. Lamming, Eds.), pp. 141-158. London, Butterworths

MELAMPY, R.M., HENRICHS, D.M., ANDERSON, L.L., CHEN, C.L. and SCHULTZ, J.R. (1966). Pituitary follicle stimulating hormone and luteinizing hormone concentrations in pregnant and lactating pigs. Endocrinology 78, 801-810

MEUSY-DESSOLLE, N. (1974). Evolution du taux de testosterone plasmatique au cours de la vie foetale chez le porc domestique. C.r. hebd. Séanc. acad. Sci., Paris 278, 1257-1260

MEUSY-DESSOLLE, N. (1975). Variations quantitatives de la testosterone plasmatique chez le porc male de la naissance à l'àge adulte. C.r. hebd. Séanc. acad. Sci., Paris 281, 1875-1878

MOON, Y.S. and HARDY, M.H. (1973). The early differentiation of the testis and interstitial cells in the fetal pig and its duplication in organ cultures. Am. J. Anat. 138, 253-268

MOON, Y.S. and RAESIDE, J.I. (1972). Histochemical studies on hydrosteroid dehydrogenase activity of fetal pig testes. Biol. Reprod. 7, 278-287

MOON, Y.S., HARDY, M.H. and RAESIDE, J.I. (1973). Biological evidence for androgen secretion by the early fetal pig testes in organ culture. Biol. Reprod. 9, 330-337

MORAT, M. (1977). Action morphogène des hormones gonadotropes sur les cellules de Leydig du verrat. I. Effects de l'hypophysectomie. Arch. Anat. microsc. Morph. exp. 66, 119-142

MORAT, M., LOCATElLI, A., TORQUI, M., CHEVALIER, M., CHAMBON, M., and 
DUfaure, J.P. (1980). Effects de l'hypophysectomie puis de l'administration de la gonadotropine HCG sur le taux de testostérone et sur la structure de l'épididyme et des glandes accessoires chez le verrat. Reprod. Nutr. Dev. 20, 61-76

OHNO, S. (1977). The Y-linked H-Y antigen locus and the X-linked Tfm locus as major regulatory genes of the mammalian sex determining mechanism. J. Ster. Biochem. 8, 585-592

PELLINIEMI, L.J. (1975a). Ultrastructure of gonadal ridge in male and female pig embryos. Anat. Embryol. 147, 19-34

PELLINIEMI, L.J. (1975b). Ultrastructure of the early ovary and testis of pig embryos. Am. J. Anat. 144, 89-112

PRICE, D. and ORTIZ, E. (1965). The role of fetal androgen in sex differentiation in mammals. In Organogenesis, (R.L. de Haan and H. Ursprung, Eds.), pp. 629-652. New York, Holt, Rinehart and Winston

RAESIDE, J.I. and MIDDLETON, A.T. (1979). Development of testosterone secretion in the fetal pig testis. Biol. Reprod. 21, 985-989

RAESIDE, J.I. and SIGMAN, J. (1975). Testosterone levels in early fetal testes of domestic pigs. Biol. Reprod. 13, 318-321

RAMALEY, J.A. (1979). Development of gonadotropin regulation in the prepubertal mammal. Biol. Reprod. 20, 1-31

RITZEN, E.M. and BOCTANI, C. (1981). Cyclic secretion of proteins by the rat seminiferous tubule, depending on the stage of spermatogenesis. Int. J. Androl. In press.

ROMMERTS, F.F.G. and BRINKMANN, A.O. (1981). Modulation of steroidogenic activities in testis Leydig cells. Molec. Cell. Endocr. 21, 15-28

RUOKONEN, A. and VIHKO, R. ((1974). Steroid metabolism in testis tissue: concentrations of unconjugated and sulphated neutral steroids in boar testis. J. Ster. Biochem. 55, 33-38

SEGAL, D.H. and RAESIDE, J.I. (1975). Androgens in testis and adrenal glands of the fetal pig. J. Ster. Biochem. 6, 1439-1444

SETCHELL, B. (1978). Endocrinological control of the testis. In The Mammalian Testis, pp. 332-358. Cornell, Cornell University Press

STEINBERGER, A. (1979). Inhibin production by Sertoli cells in culture. $J$. Reprod. Fert. Suppl. 26, 31-45

STEINBERGER, E. (1971). Hormonal control of spermatogenesis. , Physiol. Rev. 51, 1-22

STEWART, D.W. and RAESIDE, J.I. (1976). Testosterone secretion by the early pig testis in organ culture. Biol. Reprod. 15, 25-28

STRAATEN, H.W.M. van, and WENSING, C.J.G. (1977). Histo-morphometric aspects of testicular morphogenesis in the pig. Biol. Reprod. 17, 467-472

STRAATEN, H.W.M. van, and WENSING, C.J.G. (1978). Leydig cell development in the testis of the pig. Biol. Reprod. 18, 86-93

SWIERSTRA, E.E. (1968). Cytology and duration of the cycle of the seminiferous epithelium of the boar; duration of the spermatozoan transit through the epididymis. Anat. Rec. 161, 171-186

TRAN, D., MEUSSY-DESSOLLE, N. and JOSSO, N. (1977). Anti-Müllerian hormone is a functional marker of foetal Sertoli cells. Nature, Lond. 269, 411-412

TRAN, D., MEUSY-DESSOLLE, N. and JOSSO, N. (1981). Anti-Müllerian activity and formation of the blood testis barrier in the testis of the developing pig. Int. J. Androl. (Abstract) 
VORSTENBOSCH, C.J.A.H.V. van, COLENBRANDER, B. and WENSING, C.J.G. (1981). The influence of fetal decapitation on the ultrastructure of Leydig cells during testicular development in the pig. Int. J. Androl. (Abstract)

WACHTEL, S.S. (1979). H-Y antigen in the mammalian fetus. Anns Biol. anim. Biochim. Biophys. 19, 1231-1237

WACHTEL, S.S. and KOO, G.C. (1978). H-Y antigen and abnormal sex differentiation. Birth Defects 14, 1-7

WELSCHEN, R., HERMANS, W.P., DULLAART, J. and DE JONGH, F.H. (1977). Effects of an inhibin-like factor present in bovine and porcine follicular fluid on gonadotrophin levels in ovariectomized rats. J. Reprod. Fert. 50, 129-131

WENSING, C.J.G. (1968). Testicular descent in some domestic mammals. I. Anatomical aspects of testicular descent. Proc. Koninklijke Nederlandse Akademie v. Wetenschap C 71, 423-434

WENSING, C.J.G., COLENBRANDER, B. and VAN STRAATEN, H.W.M. (1980). Normal and abnormal testicular descent in some mammals. In $D e$ scended and Cryptorchid Testis, (E.S.E. Hafez, Ed.), pp. 125-137. The Hague, Nijhoff

WHITEHEAD, R.H. (1904). The embryonic development of the interstitial cells of Leydig. Am. J. Anat. 3, 167-182

WROBEL, K.H. (1969). Zur Feinstruktur des Samenblasenepithels beim Schwein. Zent. VetMed. Reihe A 16, 400-415

WROBEL, K.H. and DIERICHS, R. (1975). Wachstum and Differenzierung der Sertolizellen im Schweinehoden während des postnatalen Ontogenese. Anat. Anz. 69, 723-724

WROBEL, K.H. and FALLENBACHER, E. (1974). Histologische und Histochemische Untersuchung zur postnatalen Ontogenese des Nebenhodens beim Schwein. Anat. Histol. Embryol. 3, 85-99

ZIECIK, A.J. and FLINT, A.P.F. (1980). Gonadotrophin-like substance in pig placenta and embryonic membranes. $J$. Endocr. 85, 25P

ZIETSCHMANN, O. and KROLLING, O. (1955). Die Entwicklung des Harngeslechtsapparates. Lehrbuch der Entwicklungsgeschichte der Haustiere, pp. 373-412. Berlin, P. Parey 